\title{
Screening of Proteolytic Enzymes of Streptomyces sp. Local Strain and Their Characterization
}

\author{
DERI YURATMOKO, NISA RACHMANIA MUBARIK, AND ANJA MERYANDINI* \\ Department of Biology, Faculty of Mathematics and Natural Sciences, Institut Pertanian Bogor, \\ Darmaga Campus, Bogor 16680, Indonesia
}

\begin{abstract}
Protease of two Streptomyces sp. strain were chosen for characterization because of the large clear zone surrounding the colony in nutrient agar media containing $1 \%(\mathrm{w} / \mathrm{v})$ skim milk. Extracellular protease from the two isolates SLW 8-1 and 45I-3 were characterized following incubation of the isolate in Nutrient Broth media containing skim milk or chicken feather $(1 \%)$. The optimum activity of the protease SLW 8-1 was at $\mathrm{pH} 9$ and $80{ }^{\circ} \mathrm{C}$, whereas that of the keratinase was at $\mathrm{pH} 6.5$ and $70{ }^{\circ} \mathrm{C}$. Protease of strain 45I-3 showed its optimum activity at $\mathrm{pH} 7.5$ and $50{ }^{\circ} \mathrm{C}$ whereas the keratinase was at $\mathrm{pH} 8.5$ and $80{ }^{\circ} \mathrm{C}$.
\end{abstract}

Key words: Streptomyces sp., protease, keratinase

Proteases are one of the important enzymes for industry. The sale of proteases constitutes around $60 \%$ of the total sales of industrial enzymes (Adinarayana et al. 2003) and around 500 tons of protease enzyme are produced every year to fulfill demand coming from industries (Crueger and Crueger 1984).

Many species of bacteria are known in relation to their ability to produce protease, such as Bacillus subtilis, Escherichia coli, Clostridium bifermentans, and Streptomyces sp. (Bockle et al. 1995; Rao et al. 1998; Petinate et al. 1999b; Adinarayana et al. 2003; Enggel et al. 2004). Besides protease, Streptomyces sp. is also able to produce keratinase, the enzyme that degrades keratin (Letourneaeu et al. 1998; Bressolier et al. 1999; Moreira et al. 2001). Keratin is abundant in the nature. It is usually found in feather, hair, nail, and horn (Ignatova et al. 1999). The presence of many cystein bridges or disulfide bonds, hydrogen bonds, and hydrophobic interactions in keratin structure make this substrate very stable, rigid, and it can hardly be degraded by common proteolytic enzymes (Lin et al. 1992; Bockle et al. 1995; Bressolier et al. 1999).

The test on keratinolytic activity is usually conducted by using flour made from chicken feathers. Lintang (2003) stated that the amino acid content in chicken feather flour is very similar to the amino acids contained in keratin, e.g. the amount of the amino acid serine, arginine, and proline. Keratin in chicken feathers contains some nutrients, which are $81 \%$ crude protein, $7 \%$ crude fat, $1 \%$ crude fiber, $0.33 \%$ calcium, and $0.55 \%$ phosphorus. The high nutrient content in chicken feathers suggest this is a good feeding substance. The constraints faced in using chicken feathers for feed is the difficulty in digesting the feathers because keratin is not water soluble. A treatment which is usually applied to make the feathers more easily digestable is to use high pressure and high temperature. This treatment, however, needs a very large amount of energy and causes a loss of a large amount of its amino acid contents (Ignatova et al. 1999). A

\footnotetext{
${ }^{\ddagger}$ Present address, PT. Panjang Jiwo, Jalan Daan Mogot Km. 19 Tangerang, Tanah Tinggi 15122, Indonesia

*Corresponding author, Phone/Fax: +62-251-622833, E-mail: ameryandini@yahoo.com
}

biological approach to treat the waste of chicken feathers can be seen as an alternative solution.

\section{MATERIALS AND METHODS}

Screening of Proteolytic Streptomyces Strains. Culturing a strain from the Microbiology Laboratory, Department Biology, Institut Pertanian Bogor was conducted by growing the strains on nutrient agar with $1 \%$ skim milk (NAS media). The culture was then incubated for 7-8 days at room temperature. Strains which produced protease were characterized by formation of clear zone around their colony in NAS media.

Enzyme Production. Pure cultures of the strains were transferred into the NAS media and incubated for 7-8 days at room temperature. The colonies which grew in the NAS media were then harvested using cookborers (with $0.5 \mathrm{~cm}$ of diameter) and inoculated to $100 \mathrm{ml}$ of Nutrient Broth media ( $3 \mathrm{~g}$ beef extract and $5 \mathrm{~g}$ peptone in 11 of destilled water) that contained 1\% (w/v) skim milk (NBS) in Erlenmeyer sized $500 \mathrm{ml}$. The cultures were incubated at room temperature using a shaking incubator with an agitation speed of $240 \mathrm{rpm}$. From the $3^{\text {rd }}$ day of incubation, the protease activities of the cultures were assessed every $24 \mathrm{~h}$. The results, which were conducted until day $14^{\text {th }}$, were aimed at determining the optimum time to yield the crude protease activity produced. The crude extracts of protease were separated from the cell mass by centrifugation ( $8,000 \mathrm{~g}$ for around $5 \mathrm{~min}$ ).

Protease Activities. Protease activities were determined using a modified Walter (1984) method. As much as $100 \mathrm{ml}$ crude protease extract was added with $0.5 \mathrm{ml}$ of $1 \%$ (wt/vol) casein or $1 \%(\mathrm{wt} / \mathrm{vol})$ chicken feather and $0.5 \mathrm{ml}$ of $200 \mathrm{mM}$ buffer Tris-HCl $\mathrm{pH}$ 7.5. The solution was then incubated at $37^{\circ} \mathrm{C}$ for $10 \mathrm{~min}$. The reaction was stopped by adding $1 \mathrm{ml}$ of $10 \%(\mathrm{wt} / \mathrm{vol})$ trichloroacetic acid (TCA) with continued incubation at $10{ }^{\circ} \mathrm{C}$ for $10 \mathrm{~min}$. The next step was centrifugation of the reaction solution at $8,000 \mathrm{~g}$ for $10 \mathrm{~min}$. The supernatant $(0.75 \mathrm{ml})$ was added to $2.5 \mathrm{ml} \mathrm{Na}_{2} \mathrm{CO}_{3} 0.5 \mathrm{M}$ and $0.5 \mathrm{ml}$ Folin Ciocalteau reagent (1:2), strongly shaken, and incubated for $10 \mathrm{~min}$ at room temperature and its absorbance read at $578 \mathrm{~nm}$. One unit (IU) of the enzyme 
activity is defined as the amount of enzyme that produced $1 \mu$ mol soluble tyrosine per min. One unit is equal to 16.67 nkat (Dybkaer 2001).

Protein Concentration. Amounts of protein $\left(\mathrm{mg} \mathrm{ml}^{-1}\right)$ were determined by the Bradford method (Bradford 1976). The protein standard was bovine serum albumin (BSA). Specific activity of the protease (nkat $\mathrm{mg}^{-1}$ protein) is the ratio between protease activity $\left(\mathrm{nkat} \mathrm{ml}^{-1}\right.$ ) and total protein $\left(\mathrm{mg} \mathrm{ml}^{-1}\right)$ of an extract.

Enzyme Characterization. The determination of optimum $\mathrm{pH}$ for protease and keratinase activities was conducted by assessing the extract of crude enzyme from $\mathrm{pH} 5$ until $\mathrm{pH} 9$ with interval of 0.5 units. If the optimum activity of the crude enzyme was $\mathrm{pH} 9$, the assessment was continued to $\mathrm{pH} 10$, 11 , and 12. The buffer that was used included $200 \mathrm{mM}$ citric acid (pH 5.0-6.5), 200 mM Tris- $\mathrm{HCl}$ (pH 7.0-9.0), $200 \mathrm{mM}$ glycine- $\mathrm{NaOH}$ ( $\mathrm{pH} 10.0$ ), and $200 \mathrm{mM}$ phosphate- $\mathrm{NaOH}$ ( $\mathrm{pH} 11$ and 12). The effect of $\mathrm{pH}$ on enzyme activities for each kind of substrate was monitored by using an extract of crude enzyme, based on the highest activities in their activity curve.

The determination of optimum temperature of protease and keratinase of the crude extract was conducted through assessment of enzyme activity with various incubation temperatures, which started from $30^{\circ} \mathrm{C}$ until $90{ }^{\circ} \mathrm{C}$ using $10{ }^{\circ} \mathrm{C}$ intervals. The analyses were done at optimum $\mathrm{pH}$.

\section{RESULTS}

Proteolytic Strains. A description of the six isolates of Streptomyces sp. grown in NAS media is presented in Table 1. Based on the data shown, isolates SLW 8-1, and 451-3 had a bigger clear zone compared to that of the other four isolates.

Protease Activities. On the $3^{\text {th }}$ day, the strain SLW 8-1 had not shown any protease activity. The activity started to be detected on the $4^{\text {th }}$ day. The highest activity was on the $7^{\text {th }}$ day and started to decline on the $9^{\text {th }}$ day, and with a bump in activity on the $10^{\text {th }}$ day (Fig 1).

The strain 45I-3 had a less varied patterns for protease activity. On day 3 , the enzyme activities of this strain had been detected. The peak of the activity was on day 4 , continued with the declining activities until day 6 , and increased again until day 11 (Fig 1).

Enzyme Characterization. The extract of crude protease from strain SLW8-1 shows activity at $\mathrm{pH}$ between 8.5 and

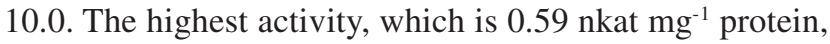
falls at $\mathrm{pH} 9$ (Fig 2). The highest activity of keratinase for this strain (3.337 nkat $\mathrm{mg}^{-1}$ protein) falls at $\mathrm{pH} 6.5$ (Fig 3).

Protease of strain 45I-3 shows activity between $\mathrm{pH}$ 6.5-8,

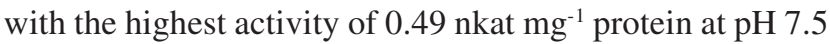

Table 1 Description of 6 isolates grown nutrient agar with $1 \%$ skim milk media after 12 days of incubation

\begin{tabular}{lcc}
\hline Isolate & Clear zone & Proteolytic index \\
\hline PD 3-27 & yes & $<1.00$ \\
SLW 8-1 & yes & 2.46 \\
234 P-16 & no & - \\
KS-1 & yes & $<1.00$ \\
PS-4-11 & yes & 1.30 \\
$45 I-3$ & yes & 1.50 \\
\hline
\end{tabular}

(Fig 4). The highest keratinase activity of strain 45I-3 is 27.59 nkat $\mathrm{mg}^{-1}$ protein, which was obtained at $\mathrm{pH} 8.5$. This strain also shows high keratinase activity at $\mathrm{pH} 7.0$. The activity is 24.31 nkat mg $^{-1}$ protein (Fig 5).

As a function of temperature, protease activity produced by strain SLW8-1 has three peaks i.e $0.63 \mathrm{nkat} / \mathrm{mg}$ protein

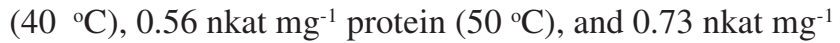
protein $\left(80^{\circ} \mathrm{C}\right)$ (Fig 6). Keratinase produced by strain strain SLW8-1 has optimum temperature at $70{ }^{\circ} \mathrm{C}$ with an activity of $4.559 \mathrm{nkat} \mathrm{mg}^{-1}$ protein (Fig 7).

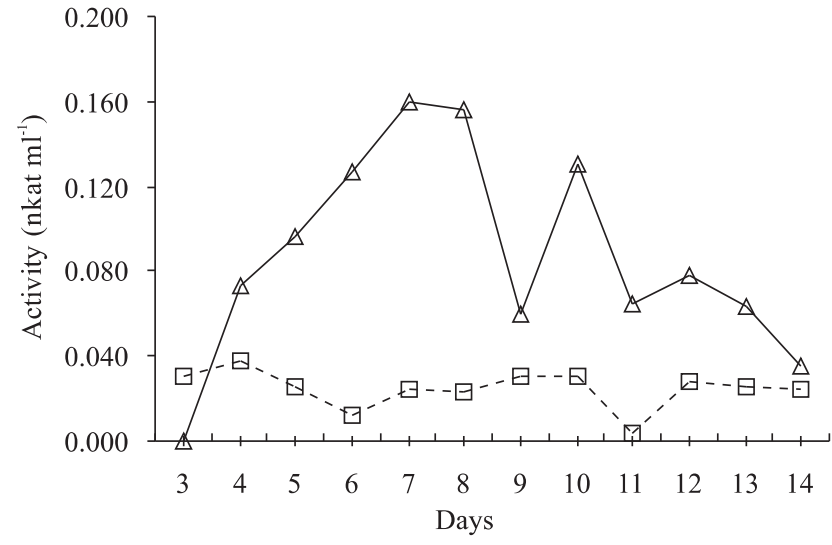

Fig 1 Activity curves from SLW8-1 and 45I-3 proteases measured at $\mathrm{pH} 7.5$ and $37^{\circ} \mathrm{C}$. $-\square$ - Protease 451-3, $\triangle$ Protease SLW8-1 $\left(\mathrm{U} \mathrm{ml} l^{-1}\right)$.

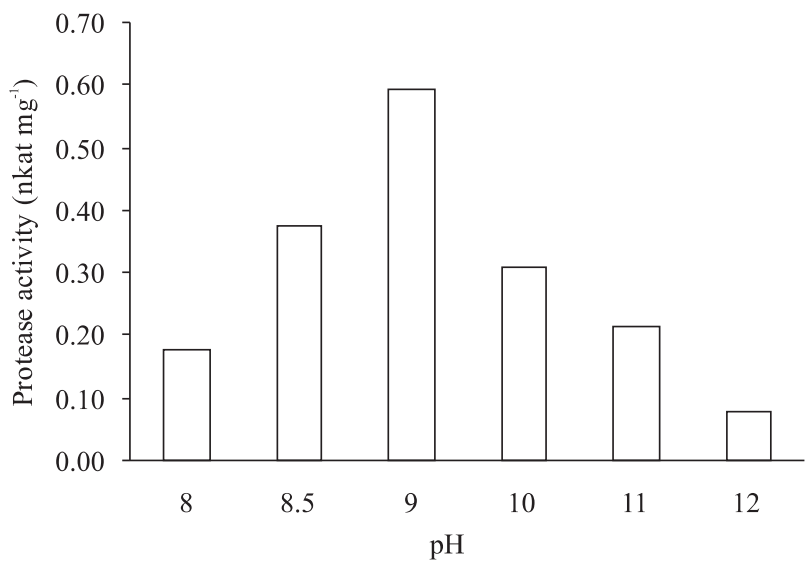

Fig 2 Protease activities from strain SLW8-1 as a function of $\mathrm{pH}$ at $37^{\circ} \mathrm{C}$.

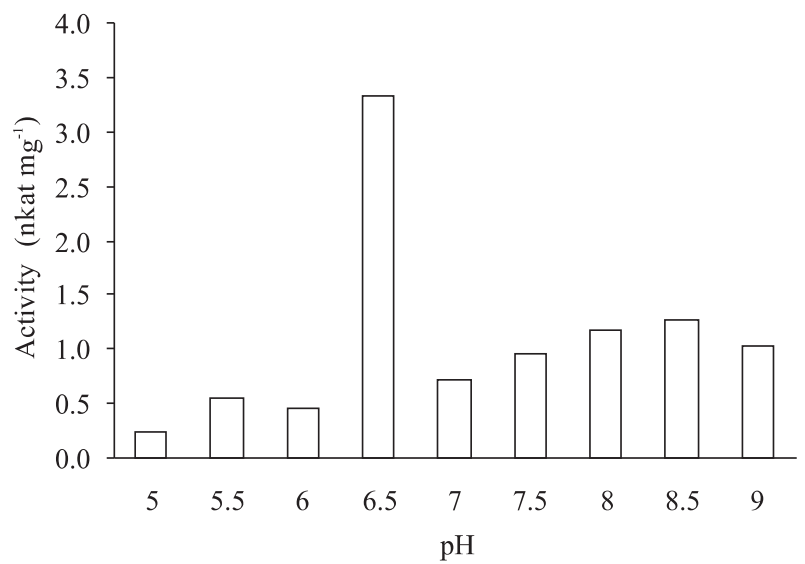

Fig 3 Keratinase activity from strain SLW8-1 as a function of $\mathrm{pH}$ at $37^{\circ} \mathrm{C}$. 


\section{DISCUSSION}

Although the diameter of the clear zone in solid media is not always correlated with the high activity of protease production in liquid media, the method is often used to precisely identify whether or not the isolates produce extracellular protease. Many bacteria are known for their ability to produce protease (Rao et al. 1998). Each of the bacteria isolates of the same genus produces a different quality and of protease having different characteristics. The addition of $1 \%(\mathrm{w} / \mathrm{v})$ skim milk to the NA media was intended to induce the bacteria to synthesize protease.

Beyond its optimum time, protease activities continued to decline. The decrease was considered to result from autolysis process of the protease itself. Decreasing amounts of substrate, due to hydrolysis that occurred by extracellular protease produced previously, is also considered to contribute some effect to the decline of the protease activities beyond its optimum period.

Feather meal can be used to induce keratinase activity. Vibrio sp. strain Kr6 and Chryseobacterium sp. produced higher yields of keratinase using feather meal or raw feather as a casein substrate (Sangali and Brandelli 2000; Brandelli and Riffel 2005).

Protease of strain SLW8-1 belongs to the alkaline proteases, while its keratinase belongs to the $\mathrm{pH}$ neutral group of enzyme. Strain 45I-3, on the other hand produces, a neutral protease and an alkaline keratinase. A protease which is active in alkaline condition has also been reported by Petinate et al. (1999a) for enzymes produced by Streptomyces cyaneus ( $\mathrm{pH}$ 9), Letourneau et al. (1998) for protease produced by Streptomyces sp. S.K ${ }_{1-02}(\mathrm{pH} 10)$, and Adinarayana et al. (2003) for protease produced by Bacillus subtilis $\mathrm{PE}-11$ ( $\mathrm{pH} 10)$. Protease with optimum activity at a neutral $\mathrm{pH}$ was reported by Lin et al. (1992) for $B$. licheniformis, Bressolier et al. (1999) for S. albidoflavus, and Moreira et al. (2001) for S. clavuligerus.

The several peak of activities which occurred in the optimum temperature determination may be due to the presence of isozymes. Isozymes are enzymes which catalyze the same reaction but shows different physical and chemical characteristics (for example isoelectric point, optimum $\mathrm{pH}$, substrate affinity, or inhibitor effect) when they are synthetised via different genes.

Letourneau et al. (1998) also reported that Streptomyces sp. S. $\mathrm{K}_{1-02}$ will rapidly produced a protease mixture with high keratinolytic activity if cultured on a simple medium supplemented with feather meal.

Some studies have also reported the ability of one strain to produce different types of protease such as Streptococcus suis which is able to produce 4 isozymes (Jobin and Grenier 2003). Streptomyces albidoflavus has been reported to produce at least 6 isozymes of protease after the exponential growth phase is completed. The production of several proteases in Streptomyces is perhaps due in-situ degradation of mycelium proteins by protease during different stages of morphological differentiation (Bressolier et al. 1999). Ginther (1979) also reported that in Streptomyces lactamdurans the production of an antibiotic and protease is closely associated with the sporulation process.
The protease of strain 45I-3 has optimum temperature at $50{ }^{\circ} \mathrm{C}$ with protease activity $0.48 \mathrm{nkat} \mathrm{mg}^{-1}$ protein (Fig 8). The similar result was reported by Moreira et al. (2001) for a protease partially purified from S. clavuligerus 3585 , and Lin et al. (1992) for protease activity of $B$. licheniformis.

In our study, the protease of strain SLW 8-1 shows optimum activity at $\mathrm{pH} 9$ and $80{ }^{\circ} \mathrm{C}$, while its optimum keratinase activity is reached at $\mathrm{H} 6.5$ and $70^{\circ} \mathrm{C}$. Also $\mathrm{pH} 7.5$ and $50{ }^{\circ} \mathrm{C}$ is needed by strain $45 \mathrm{I}-3$ to show its optimum protease activity, and $\mathrm{pH} 8.5$ and $80{ }^{\circ} \mathrm{C}$ are needed for its optimum keratinase activity.

\section{ACKNOWLEDGMENT}

The authors wish to thank Yulin Lestari for the isolates.

\section{REFERENCES}

Adinarayana K, Ellaiah P, Prasad DS. 2003. Purification and partial characterization of thermostable serine alkaline protease from a new isolated Bacillus subtilis PE-11. AAPS Pharm Sci Tech 56:19.

Bockle B, Galunsky B, Muller R. 1995. Characterization of a keratinolytic serine proteinase from Streptomyces pactum DSM 40530. Appl Environ Microbiol 6:3705-3710.

Bradford MM. 1976. A rapid and sensitive method for the quantitation of microgram quantitaties of protein in utilizing the principle of protein-dye binding. Ann Biochem 72:248-254.

Brandelli A, Riffel A. 2005. Production of an extracellular keratinase from Chryseobacterium sp. growing on raw feathers. Biotechnol $8: 35-42$.

Bressollier P, Letourneau F, Urdaci M, Verneuil B. 1999. Purification and characterization of a keratinolytic serine protease from Streptomyces albidoflavus. Appl Environ Microbiol 65:25702576.

Crueger A, Crueger W. 1984. Biotechnology: A Textbook of Industrial Microbiology. In: Brock TD (ed). Sunderland: Minauer Associater Inc.

Dybkaer R. 2001. Unit "katal" for catalytic activity. J Pure Appl Chem 73:927-931.

Enggel J, Meryandini A, Natalia L. 2004. Karakterisasi protease ekstraseluler Clostridium bifermentans R14-1-b. J Mikrobiol Indones 9:9-12.

Ginther CL. 1979. Sporulation and the production of serine protease and cephamycin C by Streptomyces lactamdurans. Antimicrob Agents Chemotherapy 15:522-526.

Ignatova Z, Gousterova A, Spassov G, Nedkov P. 1999. Isolation and partial characterisation of extracellular keratinase from a wool degrading thermophilic actinomycete strain Thermoactinomyces candidus. J Can Microbiol 45:217-222.

Jobin MC, Grenier D. 2003. Identification and characterization of four proteases produced by Streptococcus suis. FEMS Microbiol Lett 220:113-119.

Letourneau F, Soussotte V, Bressollier P, Branland P, Verneuil B. 1998. Keratinolytic activity of Streptomyces sp. S.K $\mathrm{K}_{1-02}$ : a new isolated strain. Appl Environ Microbiol 26:77-80.

Lin X, Lee C, Casale ES, Shih JCH. 1992. Purification and characterization of keratinase from a feather-degrading Bacillus licheniformis strain. Appl Environ Microbiol 58:3271-3275.

Lintang RAJ. 2003. Keratinase pendegradasi bulu ayam dari bakteri termofilik L-23 asal Sulawesi Utara [Thesis]. Bogor: Program Pascasarjana IPB.

Moreira KA, Calvalcanti MTH, Duarte HS, Tambourgi EB, de Melo EHM, Silva VK, Porto ALF, Filho JLdeL. 2001. Partial characterization of protease from Streptomyces clavuligerus using an inexpensive medium. J Brazilian Microbiol 32:215-220.

Petinate SDG, Branquinha MH, Coelho RRR, Vermelho AB, de Simone SG. 1999a. Purification and partial characterization of an extracellular serine-proteinase of Streptomyces cyaneus isolated from Brazilian cerrado soil. Appl Microbiol 87:557-563. 
Petinate SDG, Martins RM, Coelho RRR, Meirelles MNL, Branquinha MH, Vermelho AB. 1999b. Influence of growth medium in proteinase and pigment production by Streptomyces cyaneus. $J$ Mem Inst Oswaldo Cruz Rio de Janeiro 94:173-177.

Rao MB, Thanksale AM, Ghatge MS, Desphande VV. 1998. Molecular and biotechnological aspects of microbial protease. J Microb Mol Biol Rev 62:597-635.
Sangali S, Brandelli A. 2000. Feather keratin hydrolysis by a Vibrio sp. strain Kr2. J Appl Microbiol 89:735-743.

Walter HE. 1984. Proteinase (proteins substrates). Method with haemoglobin, casein and azocoll as substrate. In: Bergmeyer J, Grass M (eds). Methods of Enzymatic Analysis. $3^{\text {th }}$ Ed. Weinheim Germany: Verlag Chemie. p 270-278. 